\title{
The black flies (Diptera: Simuliidae) from Santa Catarina, Brazil
}

\author{
Sixto Coscarón?; Gilson R. P. Moreira²; Victor Py-Daniel3; Gosuke Sato4; \\ Érika S. Nascimento ${ }^{1} \&$ Marilza Maia-Herzog'
}

\begin{abstract}
${ }^{1}$ Laboratório de Simulídeos e Oncocercose, Referência Nacional em Simulídeos, Oncocercose e Mansonelose, Instituto Oswaldo Cruz/Fundação Oswaldo Cruz. Avenida Brasil 4365, Manguinhos, 21040-900 Rio de Janeiro, RJ, Brazil. E-mail: sixtoco@gmail.com; erikar@ioc.fiocruz.br; mherzog@ioc.fiocruz.br

${ }^{2}$ Departamento de Zoologia Instituto de Biociências, Universidade Federal do Rio Grande do Sul. Avenida Bento Gonçalves 9500, Agronomia, 91501-970 Porto Alegre, RS, Brazil. E-mail: gilson.moreira@ufrgs.br

${ }^{3}$ Núcleo de Pesquisas em Ciências Humanas e Sociais, Instituto Nacional de Pesquisas da Amazônia. Avenida André Araújo 2936, Petrópolis, 69011-970 Manaus, AM, Brazil. E-mail: pydaniel@inpa.gov.br

${ }^{4}$ Rua Franklin Máximo Pereira 218/103, Centro, 88302-020 Itajaí, Santa Catarina, Brasil. E-mail: gdsato@brturbo.com.br
\end{abstract}

\begin{abstract}
The Simuliidae fauna from the Santa Catarina state, Brazil, was documented, based primarily on specimens deposited in the collections of the Instituto Oswaldo Cruz, Brazil and the La Plata Museum, Argentina. The results of our survey are organized by mesoregion and by municipality. Of the 51 municipalities where black flies were recorded, 46 represented new unpublished locality records. A total of 29 species belonging to two genera and eight subgenera were found, among which five are new records for the Santa Catarina state. The species recorded are (new records are marked with a *): Lutzsimulium hirticosta, Simuliium (Chirostilbia) acarayense, S. (Chirostilbia) distinctum, S. (Chirostilbia) empascae, S. (Chirostilbia) pertinax, S. (Chirostilbia) riograndense, S. (Chirostilbia) subpallidum, S. (Ectemnaspis) dinellii, S. (Ectemnaspis) lutzianum, S. (Ectemnaspis) perflavum, S. (Hemicnetha) rubrithorax, S. (Inaequalium) botulibranchium, S. (Inaequalium) clavibranchium, S. (Inaequalium) inaequale, S. (Inaequalium) itaunense, S. (Inaequalium) nogueirai, S. (Inaequalium) subclavibranchium, S. (Inaequalium) subnigrum, S. (Inaequalium) travassosi, S. (Notolepria) paraguayense*, S. (Psaroniocompsa) anamariae*, S. (Psaroniocompsa) angrense, S. (Psaroniocompsa) auripellitum, S. (Psaroniocompsa) auristriatum*, S. (Psaroniocompsa) incrustatum, S. (Psaroniocompsa) jujuyense, S. (Psaroniocompsa) limbatum*, S. (Psaroniocompsa) minuanum*, and S. (Thyrsopelma) orbitale.
\end{abstract}

KEY WORDS. Black flies; Lutzsimulium; Simulium; biodiversity.

Black flies, a common nuisance for humans and domestic animals, often pose a public health problem as well. Besides causing severe immunological reactions, black flies are vectors of several diseases such as onchocerciasis and mansonellosis (SHelley et al. 2010). In the Southern region of Brazil, black flies have an important socio-economic impact (Dellome-FilHo 1991). In this context, the appropriated knowledge of existing black fly collections and biotaxonomy, together with socio-economic information about the regions affected by them, are extremely important to establish the measures for their control and prevention of diseases related to them as well.

There are only two preliminary studies on the black fly diversity for the Santa Catarina state (Moreira \& Py-Daniel 1986, Mouga et al. 2005). These studies reported 25 species for the Joinville municipality, located in the Northern mesoregion, where the importance of nuisance caused by black fly bites has been recognized for a long time, with respect to both humans and livestock. Herein, we document the black fly distribution for all the Santa Catarina state mesoregions, presenting a biodiversity analysis by calculating the species abundance in each mesoregion.

\section{MATERIAL AND METHODS}

The state of Santa Catarina is situated in southern Brazil, between latitude $25^{\circ} 57^{\prime} 41^{\prime \prime}$ and $29^{\circ} 23^{\prime} 55^{\prime \prime}$ S, and longitude $48^{\circ} 19^{\prime} 37^{\prime \prime}$ and $53^{\circ} 50^{\prime} 00^{\prime \prime} \mathrm{W}$, and is divided into six distinct mesoregions (Governo do Estado de Santa Catarina 2002, PANDOLFo et al. 2002, IBGE 2007; Fig. 1). The state economy relies primarily on agriculture, which accounts for most of the national poultry, beef and pork exports. About $40 \%$ of the inhabitants reside in rural areas, with the remaining population living in urban areas (IBGE 2007). With several well preserved beaches, the Atlantic coast is known for its tourism activity mainly during the summer. Two major vegetation types are present: the coastal forest (= Atlantic Rain Forest), in the east (mesoregions B, D-F), and the Semi-deciduous forest, which covers the western portion of the State (mesoregion A). The 


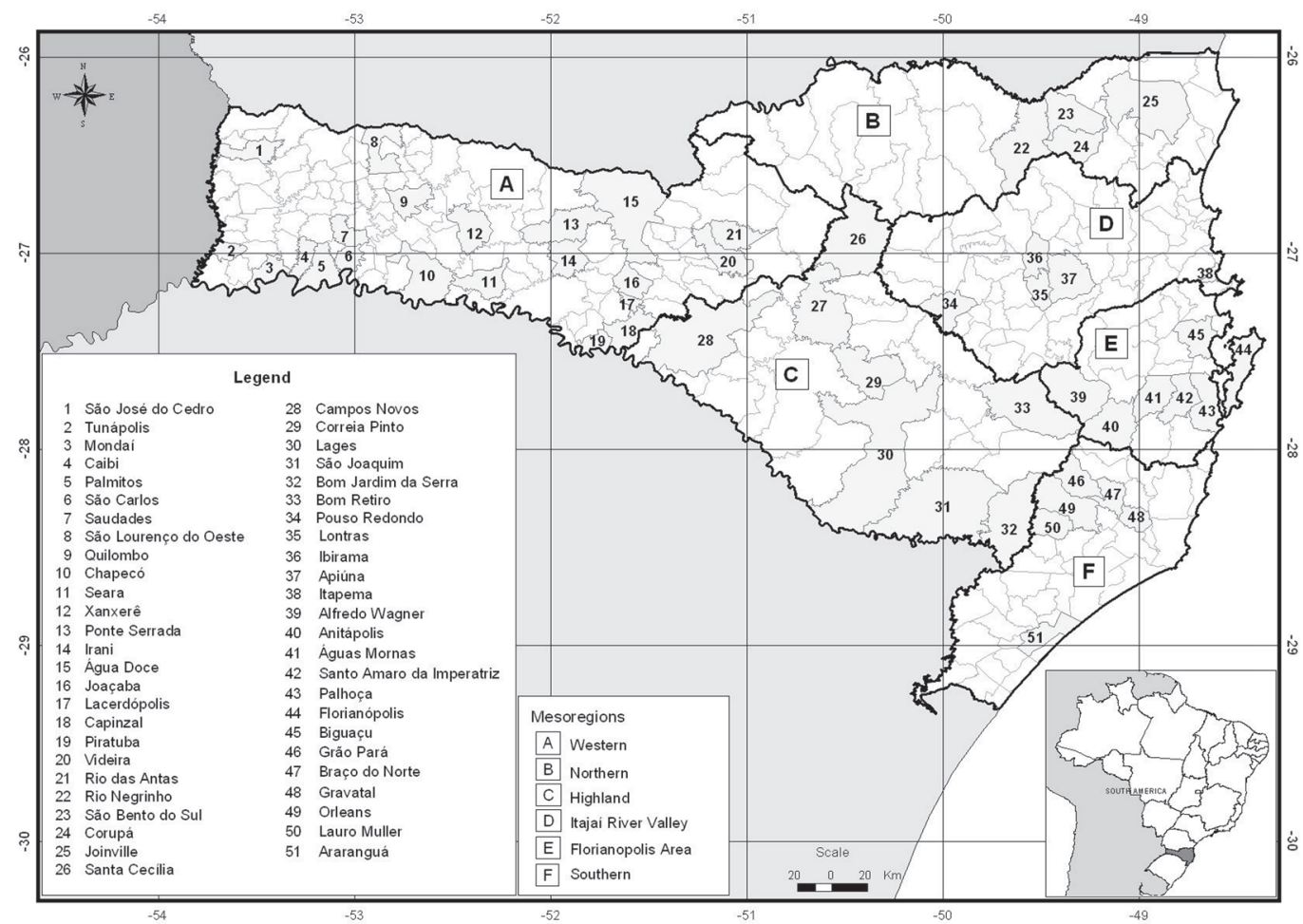

Figure 1. Santa Catarina municipalities where Simuliidae have been recorded, grouped by mesoregion.

former experiences warm and wet weather throughout the year, whereas the latter has a dry season (reviewed by Morellato \& HadDad 2000). Between these two areas, the Highlands (mesoregion $\mathrm{C}$ ) form a plateau at the top of the mountain chain that runs along the coastline from southern to northeastern Brazil, and is covered by a mosaic of grasslands and Araucaria forests, also called "Campos" (see Overbeck et al. 2007).

The specimens used in this study are deposited in the Simuliidae and Onchocerciasis Laboratory collection of the Instituto Oswaldo Cruz, Rio de Janeiro, Brazil, and in the Simuliidae collection of the La Plata Museum, La Plata, Argentina. Access to the material from the Simuliidae and Onchocerciasis Laboratory collection was done through the database "Access Platform" - BIOCOLLECTION System Administrator for Biological Collections 1.0 - LSO/IOC/FIOCRUZ. Immature (pupae and larvae) and adults were preserved in $80 \%$ ethanol. Identification was conducted using a stereoscopic microscope and, when necessary, specimens were slide-mounted and examined under a compound microscope. Morphological characters of the adult, larva and pupa were used for the identification, adopting the taxonomic criteria described in CosCARón \& COSCARÓN-ARIAS (2007). Black flies host preference data are based on information from COSCARÓN \& COSCARÓN-ARIAS (2007) and SHelley et al. (2010). The distribution of each species was quantified for each municipality of the Santa Catarina State.

\section{RESULTS AND DISCUSSION}

A total of 3,520 specimens of 29 black fly species were examined, with five new records for the state of Santa Catarina: Simulium (Notolepria) paraguayense Schrottky, 1909, Simulium (Psaroniocompsa) anamariae Vulcano, 1962, Simulium (Psaroniocompsa) auristriatum Lutz, 1910, Simulium (Psaroniocompsa) limbatum Knab, 1915 and Simulium (Psaroniocompsa) minuanum Strieder \& Coscarón, 2000. The distribution of the species in the 51 municipalities is shown in Table I. Considering the size of the sample, it was observed that the municipalities of Joinville, Água Doce, Irani, Rio das Antas, Saudades, and Seara (Western mesoregion), Campos Novos (Highland mesoregion), Araranguá, Grão Pará, and Orleans (Southern mesoregion) account for most of the specimens collected.

The data showed that the subgenus Chirostilbia Enderlein, 1921 with six species, and Psaroniocompsa Enderlein, 1934 with eight species have the greatest representation in the Santa Catarina black fly fauna. Considering the proportional distribution within the 51 municipalities where the survey took place, the subgenus Inaequalium Coscarón \& Wygodzinsky, 1984 was poorly represented, with nine species. Some species - Simulium (Chirostilbia) pertinax Kollar, 1832, Simulium (Ectemnaspis) dinellii Joan, 1912, Simulium (Notolepria) paraguayense, Simulium (Psaroniocompsa) incrustatum Lutz, 1910, and Simulium 


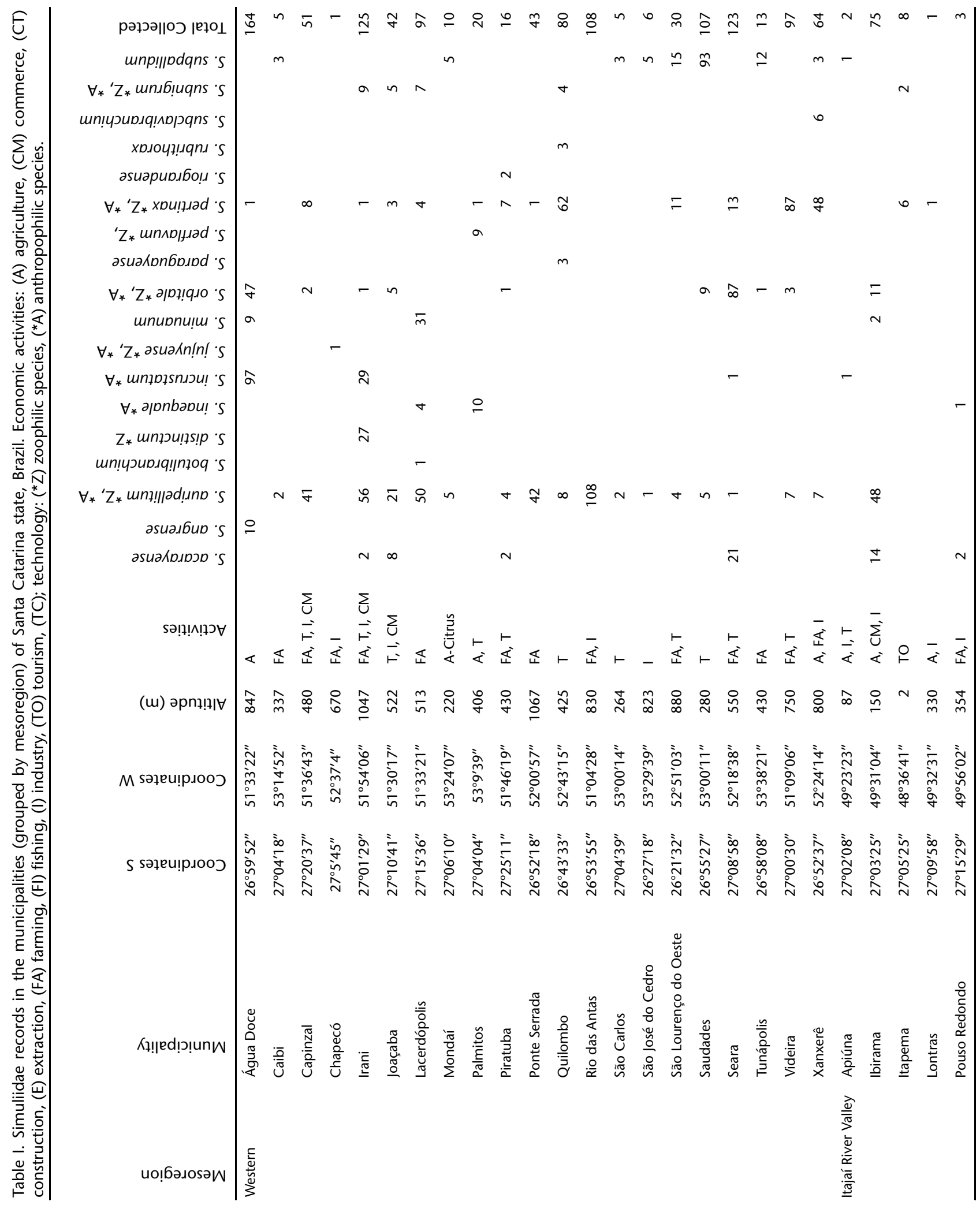




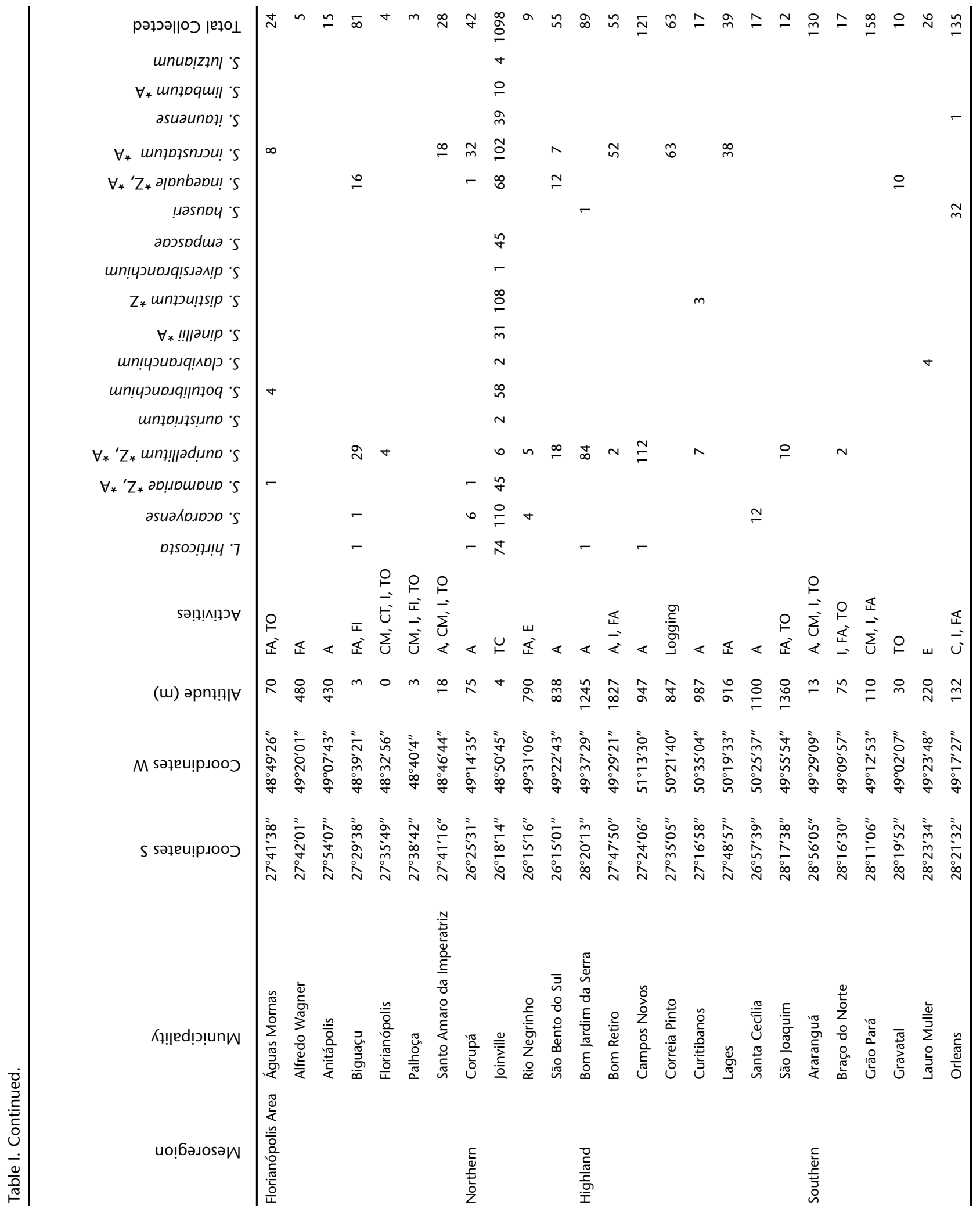




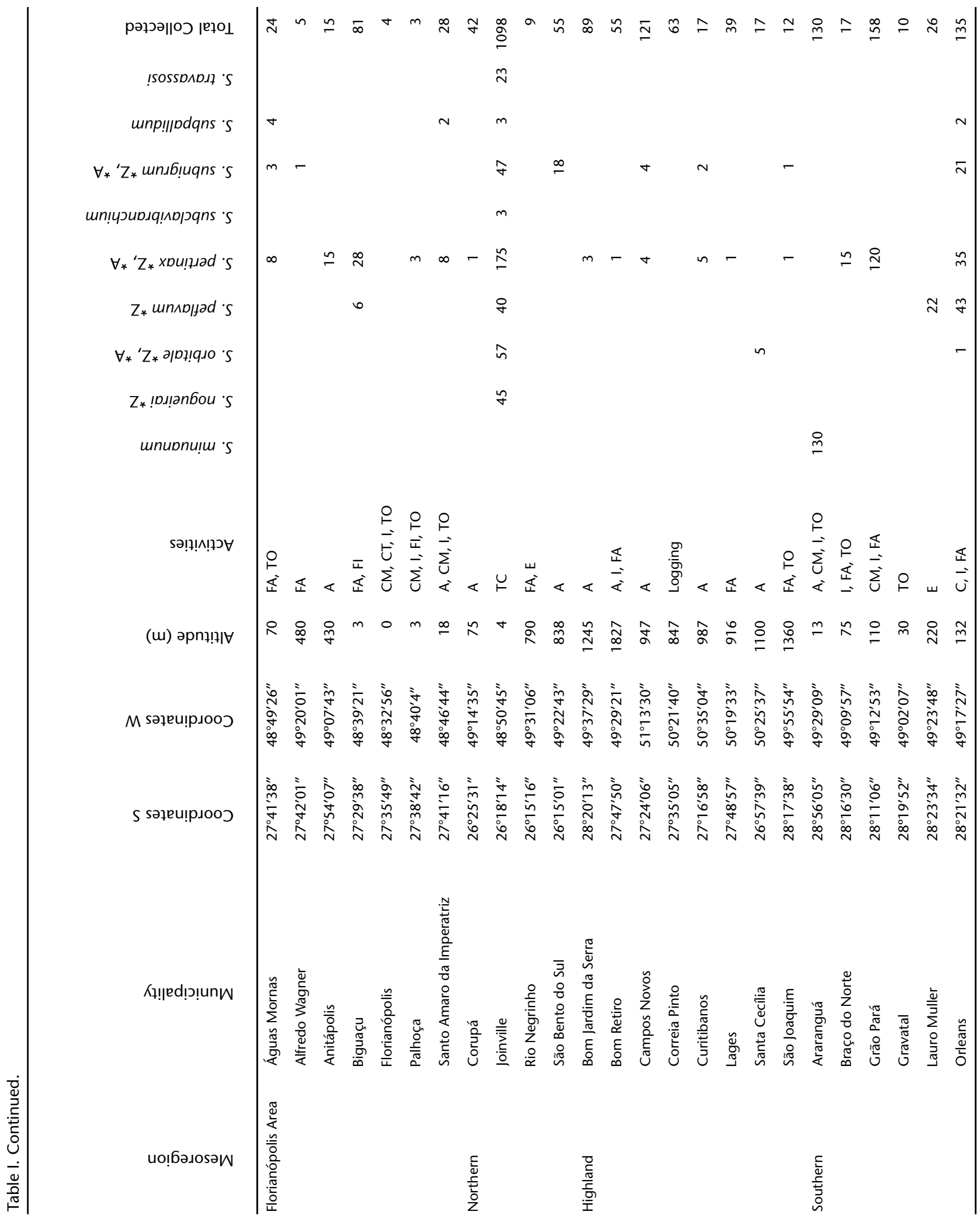


(Psaroniocompsa) limbatum - are considered voracious pests in the region, regardless of their host preferences (according to the author's experience during collecting).

The new records for the Santa Catarina state are not surprising, thus demonstrating only the existence of gaps in the knowledge of this family for Santa Catarina. Most of them can be certainly associated with the black fly fauna that is characteristic of the Paraná sub region and their provinces (sensu Morrone 2006), to which some are certainly recognized as endemic (Shelley et al. 2010). Our results show that anthropophilic and zoophilic black fly species, in spite of varying in diversity within a short spatial scale, are widespread in the Santa Catarina State. The apparent similarity between the Western and Highland black fly fauna should be further explored; it could be explained by the geographical characteristics that are shared by such areas, since both are located within Semi-deciduous Atlantic forest. From a broad scale perspective, their diversity, and maybe abundance, is apparently greater on the Eastern and Western portions of the State. Compared to the middle highlands where plateau grasslands prevail, these regions, and specially those located in the coastal forest are richer on streams and rivers that run on the strong slopes of mountain chains existing locally, besides being wetter and warmer throughout the year, favoring the abundance and diversity (Morellato et al. 2000). Together, these aspects would certainly contribute to such a pattern of typical heterothermic, restricted water flow immature stage inhabitants, such as black flies.

\section{ACKNOWLEDGEMENTS}

Clarisse P. Faria produced the map showing municipalities in the state of Santa Catarina. Érika A.L. Abrantes helped to retrieve information from the database of the Simuliidae collection of the Instituto Oswaldo Cruz. Financial support for this research was granted in part by the Conselho Nacional de Desenvolvimento Científico e Tecnológico.

\section{LITERATURE CITED}

Coscarón, S. \& C.L. CosCarón-Arias. 2007. Neotropical Simuliidae (Diptera: Insecta). J. Adis; J.R. Arias; G. Rueda-Delgado \& K.M. Wantzen (Eds). Aquatic Biodiversity in Latin America. Sofia, Pensoft, vol. 3, 685p.

Submitted: 06.V.2010; Accepted: 30.XII.2010.

Editorial responsibility: Pedro Gnaspini
Dellome-Filho, J. 1991. Simuliofauna do rio Marumbi (Morretes, PR, Brasil). I. Coleta e criação; dados meteorológicos e físico-químicos do criadouro; adultos (Diptera, Simuliidae). Acta Biológica Paranaense 20 (1, 2, 3, 4): 145-156.

Governo do Estado de Santa Catarina. 2002. Plano integrado de recursos hídricos da bacia hidrográfica do rio Tubarão e complexo lagunar. Florianópolis, Governo do Estado de Santa Catarina, Atividades Preliminares, Tomo I, Florianópolis, vol. 1, 295p.

IBGE. 2007. Geociências - Divisão regional do Brasil em zonas fisiogeográficas. Available online at: http://www.ibge.gov. br[Accessed: 01.IX.2009].

Moreira, G.R.P. \& V. Py-Daniel. 1986. Levantamento das espécies de simulídeos da região de Joinville, Santa Catarina. Secretaria da Agricultura e do Abastecimento. Florianópolis. Empresa Catarinense de Pesquisa Agropecuária, Relatório Técnico - Pesquisa em Andamento, vol. 59, 3p.

Morellato, L.P.; D.C. Talora; A. Takahasi; C.C. Bencke; E.C. Romera \& V.B. Zipparro. 2000. Phenology of Atlantic Rain Forest trees: A comparative study. Biotropica 32: 811-823.

Morrone, J.J. 2006. Biogeographic areas and transition zones of Latin-America and the Caribbean Islands based on panbiogeographic and cladistics analyses of the entomofauna. Annual Review of Entomology 51: 467-494.

Mouga, D.M.D.; O. Souza \& S. SetTr. 2005. Levantamento das espécies de borrachudos (Diptera, Simuliidae) ocorrentes no Município de Joinville, Santa Catarina. Available online at: http://www.seb-ecologia.org.br/viiceb/resumos/ 417a.pdf [Accessed: 01.IX.2009].

Overbeck, G.E.; S.C. Muller; A. Fidelis; J. Pfadehauer; V.D. Pillar; C.C. Blanco; I. Boldrini; R. Botha \& E.D. Forneck. 2007. Brazil's neglected biome: The South Brazilian Campos. Perspectives in Plant Ecology, Evolution and Systematics 9: 101-116.

Pandolfo, C.; H.J. Braga; V.P. Silva; A.M. Massignan \& V.M.R.Thorme. 2002. Atlas climatológico digital do Estado de Santa Catarina. Epagri. Available online at: http:// www.epagri.rct.sc.br [Accessed: 01.IX.2009].

Shelley, A. J.; L. M. Hernández; M. Maia-Herzog; A. P. A. Luna Dias \& P. R. Garritano. 2010. The Blackflies (Diptera: Simuliidae) of Brazil. In: J.R. Arias; S. Golovatch; K.M. Wantzen \& E. Dominguez (Eds). Aquatic Biodiversity in Latin America. Sofia, Pensoft, vol. 1, 821p. 